\title{
BIOLOGIC SCAFFOLDS FOR MUSCULOTENDINOUS TISSUE REPAIR
}

\author{
Neill J. Turner ${ }^{1,2}$ and Stephen F. Badylak ${ }^{1,2, *}$ \\ ${ }^{1}$ McGowan Institute for Regenerative Medicine, University of Pittsburgh, Pittsburgh, PA, USA \\ ${ }^{2}$ Department of Surgery, University of Pittsburgh, Pittsburgh, PA, USA
}

\begin{abstract}
Traumatic injuries to the musculoskeletal system are common events and volumetric muscle loss (VML) is no longer a rare occurrence. Surgical intervention is typically the only option for restoration of partial function. Surgical intervention for VML however does not regenerate the lost tissue and typically results in alterations of both the anatomy and biomechanics at the site of injury. Non-traditional approaches to the restoration of functional musculoskeletal tissue, including those provided by tissue engineering and regenerative medicine strategies, become viable alternative therapies when the expected outcome is bleak. One such strategy involves the delivery of constructive cues and modulation of the micro-environmental niche via biologic scaffold materials. These materials ideally retain the native structure and composition of the extracellular matrix of the tissue from which they are derived. Some of the recent advances in the use of biologic scaffolds to target key stages of the musculotendinous repair process and promote the restoration of functional tissue are described herein.
\end{abstract}

Keywords: Extracellular matrix; biologic scaffold; skeletal muscle; tendon; repair; tissue regeneration.

\author{
*Address for correspondence: \\ Dr Stephen Badylak \\ McGowan Institute for Regenerative Medicine \\ University of Pittsburgh \\ Bridgeside Point 2 \\ 450 Technology Drive \\ Pittsburgh, PA 15219, USA.
}

Telephone Number: 1-412-624-5253

FAX Number: 1-412-624-5256

Email: badylaks@upmc.edu

\section{Introduction}

Traumatic injuries to the musculoskeletal system are common events and volumetric muscle loss (VML) is no longer a rare occurrence. Survival following limb salvage for extremity tumors is contributing to the increased incidence of VML. More than $55 \%$ of sportrelated injuries involve skeletal muscle and/or tendon (Beiner and Jokl, 2001; Counsel and Breidahl, 2010; Garrett, 1996; Jarvinen et al., 2005; Jarvinen et al., 2000; Lehto and Jarvinen, 1991) and the most common injuries involve tears, lacerations and contusions, which have a robust capacity for restoration of full function. The presence of mononuclear myogenic satellite cells is largely responsible for the regenerative potential of skeletal muscle (Beiner and Jokl, 2001; Garrett, 1996; Jarvinen et al., 2005; Jarvinen et al., 2000; Lehto and Jarvinen, 1991). However, if more than $20 \%$ of a given muscle is lost, the natural repair process will typically fail to repair the defect resulting in scar tissue formation and a loss of function (Aarimaa et al., 2004; Crow et al., 2007; Garrett et al., 1984; Menetrey et al., 1999; Terada et al., 2001). In such cases, surgical intervention may be the only option for restoration of partial function. However, surgical intervention does not regenerate the lost tissue and typically results in alterations of the anatomy and biomechanics at the site of injury (Tesch et al., 2008). It is not uncommon for extensive traumatic injury to result in amputation.

Non-traditional approaches to the restoration of functional musculotendinous tissue, including those provided by tissue engineering and regenerative medicine strategies, become viable alternative therapies when the expected outcome is bleak. As our understanding of developmental biology and the cellular and biochemical cues associated with tissue and organ formation, including musculotendinous tissue, has increased, an in vivo regenerative medicine strategy has emerged. This strategy involves the delivery of constructive cues and modulation of the microenvironmental niche via biologic scaffold materials. These materials ideally retain the native structure and composition of the extracellular matrix (ECM) of the tissue from which they are derived. The pathobiology of musculotendinous injury repair and some of the recent advances in the use of biologic scaffolds to target key stages of the repair process and promote the restoration of functional tissue are described herein.

\section{Pathobiology of musculotendinous tissue repair}

To discuss the concepts of tissue repair, tissue regeneration and constructive remodeling as they relate to 


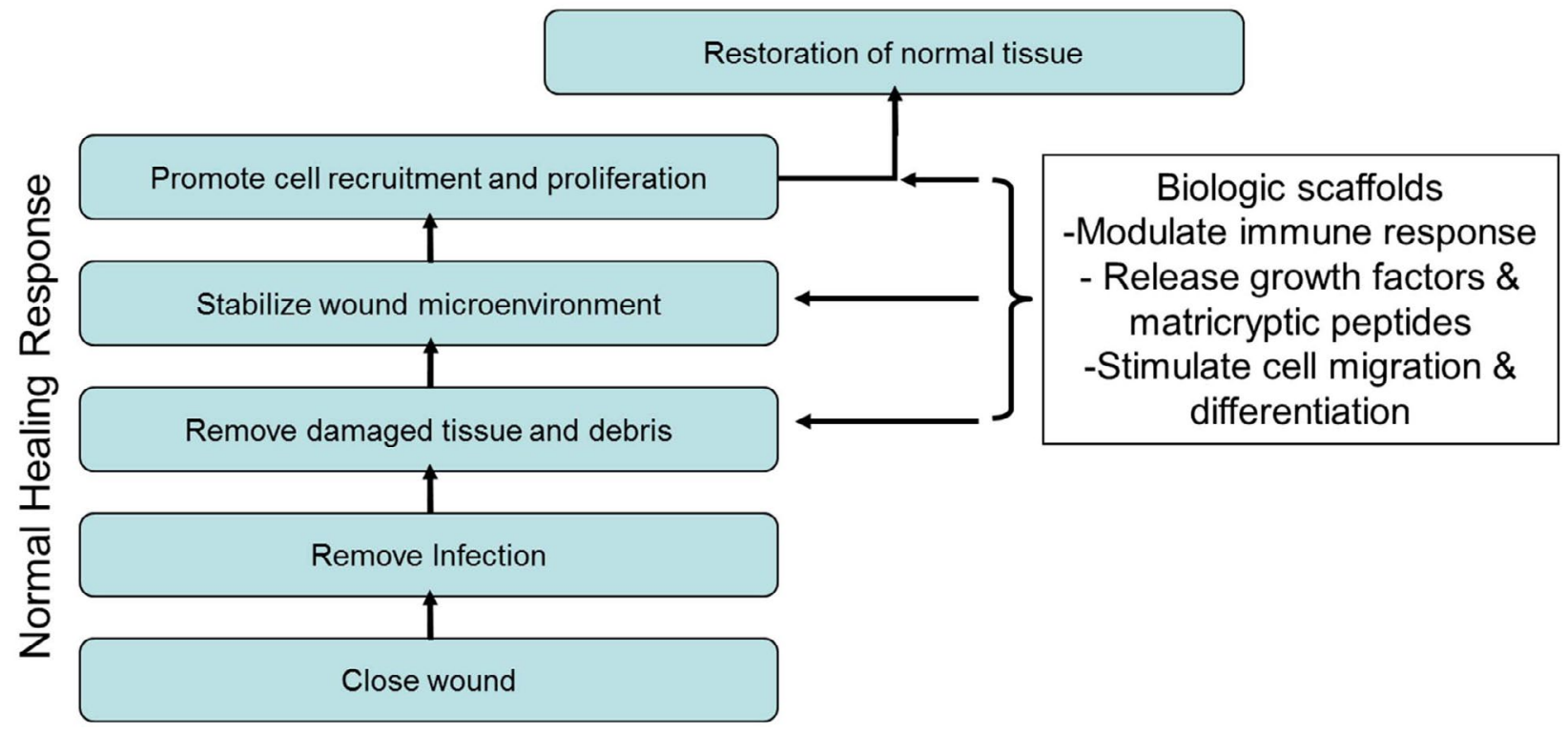

Fig. 1. An overview of wound healing and the potential for intervention with biologic scaffolds.

musculoskeletal regenerative medicine, an understanding and definition of these terms as used in this manuscript is necessary. All tissues and organs within the body have a capacity to repair, but very few have a capacity to regenerate. Tissue repair represents a response to damage or loss of tissue that leads to restoration of tissue continuity by the formation of scar tissue without the complete replacement of normal functional tissue. In contrast, regeneration restores tissue structural and functional integrity through the synthesis of new tissue that is specific and appropriate to that anatomic location. Stated differently, regeneration restores normal tissue structure and function while repair does not. Adults typically respond to traumatic injury, in most tissues, by repairing the injured anatomic site. However, certain body sites, such as the bone marrow, selected epithelial tissues and liver, have the capacity for spontaneous regeneration following injury. The goal of a regenerative medicine approach is to modify the default response to injury toward a regenerative process.

While true regeneration would result in tissue that was indistinguishable from uninjured tissue, the response elicited by inductive biologic scaffolds may more appropriately be termed constructive remodeling; i.e. the restoration of at least partial, site-appropriate, structurefunction relationships. Fig. 1 shows an overview of the wound healing process and the potential points for intervention to enhance the healing process.

The normal mammalian response to tissue injury occurs in a continuum of overlapping but distinct stages: hemostasis, inflammation, new tissue formation and tissue remodeling (Gurtner et al., 2008). This repair process has been described in detail (Garrett et al., 1984; Huard et al., 2002; Jarvinen et al., 2005; Lehto and Jarvinen, 1991) and a brief overview is described herein. The first stages of wound repair, hemostasis and inflammation, occur immediately following tissue injury.
Polymorphonuclear leukocytes migrate to the wound site in response to molecular signals from damaged cells. Mononuclear cells, including monocytes that differentiate into proinflammatory macrophages, subsequently engulf and/or attempt to destroy any pathogens and necrotic debris. Macrophages play a critical role in the wound healing process, particularly that which occurs following skeletal muscle injury. Macrophage populations with a preferred phenotype sequentially accumulate in the injured muscle tissue. First, pro-inflammatory, M1 phenotype macrophages phagocytose necrotic tissue and secrete a host of cytokines that stimulate the chemotaxis and proliferation of resident progenitor cells. The M1 macrophages are followed by tissue remodeling M2 phenotype macrophages, which facilitate progenitor cell differentiation (Tidball and Villalta, 2010).

The first week to 10 days following injury is characterized by the migration and proliferation of cells within the wound site. During the repair process, nerves and blood vessels advance into the wound area. In skeletal muscle, tissue satellite cells migrate and differentiate into myoblasts that fuse with other myoblasts or with existing myofibers to form new skeletal muscle. In tendon tissue, fibroblasts and tenocytes begin to replace the necrotic tissue of the wound with new ECM, including the formation of granulation tissue. The ECM produced by these fibroblasts is mostly collagen and will ultimately constitute the bulk of the ECM within the mature tissue. Furthermore, some fibroblasts differentiate into contractile myofibroblasts, which contribute to wound contraction. There is intense interest, and controversy, regarding the contribution of stem and progenitor cell populations, such as bone marrow derived cells, to tissue repair either through differentiation or by secretion of paracrine factors that affect surrounding cells (Quintero et al., 2009; Sun et al., 2009; Tedesco et al., 2010; Ten Broek et al., 2010). 
The final stage of wound repair, remodeling, may take up to 12 months to complete and is characterized by a reduction in cell density at the wound site and maturation and organization of the ECM in response to focal microenvironmental factors, such as mechanical loading and blood supply. Macrophages, fibroblasts and myofibroblasts that are present within the wound site undergo apoptosis or migrate from the wound. In skeletal muscle this remodeling process can often be associated with marked reorganization of the muscle tissue, including the formation of forked fibers, satellite myofibers or orphan myofibers that form outside the basal lamina (Schmalbruch, 1976) and the ends of the damaged muscle fibers may not reunite, but instead form a new myotendinous junction with the interposed scar tissue. In tendinous injuries, the fibroblasts and tenocytes that remain within the wound secrete matrix metalloproteinases (MMPs), which facilitate the turnover of the ECM and the formation of a more mature tissue that consists predominantly of type I collagen, which strengthens the repaired tissue.

\section{Macrophages in response to skeletal muscle injury}

The type and intensity of the inflammatory response following injury defines the dynamic microenvironment that influences either a scarring or a constructive remodeling response. The role of macrophages in skeletal muscle injury and repair has been extensively reviewed by Tidball (Tidball, 2005; Tidball and Villalta, 2010; Tidball and Wehling-Henricks, 2007). The macrophage represents a bone marrow-derived cell that circulates as a monocyte, exits the peripheral circulation in response to chemotactic stimuli, and subsequently differentiates into a macrophage. Macrophage phenotype and the role of macrophages in normal and pathologic processes have been the subject of intense study during the past decade (Delavary et al., 2011; Fleming and Mosser, 2011; Martinez et al., 2008; Ploeger et al., 2012; Tidball and Villalta, 2010). It is now recognized that a wide spectrum of macrophage phenotypes exists, ranging from the classically activated proinflammatory M1 macrophage to the regulatory, tissue rebuilding M2 macrophage phenotype. Phenotype is determined by the profile of secreted cytokines, chemokines, effector molecules, and cell surface markers. These secreted molecules contribute to the local tissue milieu, which, in turn, has marked effects on downstream events.

The initial response to skeletal muscle injury involves a proinflammatory M1 macrophage population. The secreted effector molecules of this phenotype stimulate proliferation and migration of muscle progenitor cells, including perivascular stem cells and satellite cells (A1Shanti et al., 2008; Chen et al., 2005; Lolmede et al., 2009; Torrente et al., 2003; Wang et al., 2008; Warren et al., 2002). However, these accumulated cells fail to mature and differentiate into functional myocytes without an associated transition of the macrophage phenotype population from an M1 to the more constructive M2 phenotype (Szalay et al., 1997; Tsujinaka et al., 1996). The shift in phenotype from M1 to M2 macrophages coincides with, and is necessary for, myogenic differentiation ( $\mathrm{St}$
Pierre and Tidball, 1994), which is severely disrupted if M2 macrophages are depleted (Tidball and Wehling-Henricks, 2007). It is unknown whether there is plasticity among the tissue macrophages; that is, it is unknown whether the M1 phenotype transitions to an M2 phenotype in situ or if a separate population of infiltrating macrophages, the M2 phenotype, replaces the early arriving M1 cells, although there is evidence to suggest phenotype plasticity (Ploeger et al., 2012). Regardless, this transition is necessary for the full process of skeletal muscle regeneration to occur. The spatial and temporal pattern of this process is an area of great interest and a more detailed understanding of the process may lead to novel strategies to promote and facilitate skeletal muscle regeneration following injury. In addition, the apparent requirement for macrophages in the restoration of skeletal muscle raises interesting questions regarding the use of anti-inflammatory medications and how these affect macrophage polarization.

\section{Biologic scaffolds in skeletal muscle repair}

As described above, the natural healing response of musculotendinous injuries follows a series of distinct phases. Biologic scaffolds have been shown to effectively reprogram key stages of the wound repair by altering the wound microenvironment from one that promotes fibrosis and scar tissue formation to one that stimulates constructive remodeling of the injured tissue (Badylak et al., 2011). The ability of biologic scaffolds to alter the macrophage phenotype response, coupled with the release of latent growth factors and chemotactic degradation products, have made these materials attractive as scaffolds to promote skeletal muscle reconstruction following trauma and volumetric loss (Mase et al., 2010; Merritt et al., 2010; Turner et al., 2010).

As shown in Tables 1 and 2 a wide variety of biologic scaffolds are now commercially available that differ in their tissue source, species of origin, and methods of preparation, and a large number of animal models exist by which these biologic scaffolds are evaluated. Typically, these materials are xenogeneic in origin and would, therefore, be anticipated to elicit a proinflammatory reaction when implanted. However, when processed in a manner that effectively removes resident cells and minimally distorts the native ultrastructure, biologic scaffolds induce a macrophage response that rapidly transitions from a proinflammatory M1 phenotype to one that is predominately M2 (Ariganello et al., 2011; Badylak et al., 2008; Brown et al., 2009; Valentin et al., 2009).

While the underlying mechanisms by which biologic scaffolds direct M1 vs. M2 polarization are still largely unknown, a number of important factors that influence this process have been identified. Processing methods play a critical role in determining the type of host response which occurs (Valentin et al., 2009). Typically, ECM-based scaffolds that are not chemically cross-linked and which have minimal residual DNA content (at or below $50 \mathrm{ng} / \mathrm{mg}$ ECM dry weight) elicit an M2 macrophage polarization response with associated constructive tissue remodeling (Keane et al., 2012; Valentin et al., 2009). Chemically 
Table 1: Examples of FDA approved biologic scaffolds.

\begin{tabular}{|c|c|c|}
\hline PRODUCT & COMPANY & MATERIAL \\
\hline \multicolumn{3}{|l|}{ Porcine Tissue } \\
\hline Oasis $^{\circledR}$ Wound Matrix & Cook $^{\circledR}$ Biotech / Healthpoint & $\begin{array}{c}\text { Non-crosslinked small intestinal } \\
\text { submucosa ECM }\end{array}$ \\
\hline Surgisis $^{\circledR}$ & Cook $^{\circledR}$ Medical & $\begin{array}{c}\text { Non-crosslinked small intestinal } \\
\text { submucosa ECM }\end{array}$ \\
\hline Cuffpatch $^{\text {TM }}$ & Biomet Sports Medicine & $\begin{array}{c}\text { Crosslinked, hydrated small intestinal } \\
\text { submucosa ECM }\end{array}$ \\
\hline Restore $^{\circledR}$ & DePuy & $\begin{array}{c}\text { Non-crosslinked small intestinal } \\
\text { submucosa ECM }\end{array}$ \\
\hline Pelvicol $^{\circledR}$ & C.R. Bard Inc. & Crosslinked, hydrated dermal ECM \\
\hline Permacol $^{\mathrm{TM}}$ & Covidien & Crosslinked, hydrated dermal ECM \\
\hline \multicolumn{3}{|l|}{ Bovine Tissue } \\
\hline Xenform $^{\circledR}$ & TEI Biosciences / Boston Scientific & Non-crosslinked fetal dermal ECM \\
\hline Veritas $^{\circledR}$ & Synovis ${ }^{\circledR}$ Surgical Innovations & Crosslinked pericardial ECM \\
\hline Primatrix $^{\mathrm{TM}}$ & TEI Biosciences & Non-crosslinked fetal dermal ECM \\
\hline
\end{tabular}

Table 2: Examples of animal models of ECM-mediated skeletal muscle repair

\begin{tabular}{|c|c|c|c|}
\hline Species & Muscle group & Mechanism of Injury & Reference \\
\hline Mouse & Quadriceps & $\begin{array}{c}\text { Partial resection of tensor facia lata and } \\
\text { rectus femoris }\end{array}$ & (Sicari et al., 2012) \\
\hline Mouse & Latissimus Dorsi & $\begin{array}{c}\text { Resection of } 18 \mathrm{mg} \text { tissue } \\
\text { Resection of } \sim 50 \% \text { of muscle }\end{array}$ & $\begin{array}{c}\text { (Corona } \text { et al., 2012) } \\
\text { (Machingal } \text { et al., 2011) }\end{array}$ \\
\hline Mouse & Anterior Tibialis & Complete resection & (Perniconi et al., 2011) \\
\hline Rat & Abdominal wall obliques & Partial thickness partial resection & (Valentin et al., 2010) \\
\hline Rat & Lateral gastrocnemius & Partial resection & (Merritt et al., 2010) \\
\hline Rat & Rectus abdominus & Full thickness partial resection & (Vindigni et al., 2004) \\
\hline Rabbit & Abdominal wall & Partial resection of external oblique & (Gamba et al., 2002) \\
\hline Rabbit & Anterior tibialis & Compartment Syndrome & (Daly et al., 2011) \\
\hline Rabbit & Vastus Lateralis & Partial resection & (Kin et al., 2007) \\
\hline Dog & Quadriceps & $\begin{array}{c}\text { Partial resection of vastus lateralis and } \\
\text { vastus medialis }\end{array}$ & (Turner et al., 2010) \\
\hline
\end{tabular}

cross-linked products, or poorly-decellularized tissues, elicit an M1, pro-inflammatory response with downstream fibrosis and scar tissue formation (Badylak et al., 2008; Brown et al., 2009; Keane et al., 2012; Valentin et al., 2009). These cross-linked products promote a foreign body response as the host macrophages cannot degrade the material and effectively isolate the scaffold from the body in a fibrotic capsule. Conversely, degradable biologic scaffolds release matricryptic peptides and other bioactive molecules that signal a phenotypic change in the macrophages towards M2. The importance of macrophage phenotype in the repair of skeletal muscle has been clearly demonstrated, and the ability of an implanted material to influence this phenotypic switching may be critical in 
promoting repair in severe traumatic injuries. Of note, acellular biologic scaffolds promote a more constructive remodeling M2 macrophage phenotype than even autologous tissue grafts when used in a model of muscle regeneration (Badylak et al., 2008; Valentin et al., 2009). Reider et al. (2005) showed that decellularization of tissues does not inhibit the activation of macrophages, while Ariganello et al. (2010) demonstrated that decellularization lowered esterase and phosphatase activity, suggesting that biologic scaffolds activate alternative (M2) signaling pathways. The ability of a biologic scaffold to promote an increase in M2 polarization may be a causative factor for improved myoblast differentiation and fusion and an increase in the amount of functional muscle restored following injury.

The manipulation of the macrophage response alone cannot account for the constructive remodeling responses that result from implantation of a biologic scaffold. Additional factors play an important role the ability of ECM scaffolds to manipulate the wound microenvironment, such as the release of latent growth factors and/or degradation products that can act as chemoattractant factors for myogenic precursor cells.

Growth factors are essential regulators of the muscle repair process, controlling the proliferation and differentiation of muscle progenitor cells (Charge and Rudnicki, 2004; Ten Broek et al., 2010). The sequence of their release appears important to the control of muscle repair (Hayashi et al., 2004). Many cells essential for skeletal muscle repair release latent growth factors that are sequestered by the ECM and which only become active following degradation of this ECM during muscle repair (Kresse and Schonherr, 2001; Miura et al., 2006; Schultz and Wysocki, 2009). Biologic scaffolds are being used commonly to promote tissue repair in many body sites including muscle (Badylak, 2007; Borschel et al., 2004; Jensen and Host, 1997; Owen and Shoichet, 2010; Robinson et al., 2005; Silver and Pins, 1992; Turner et al., 2010). Several studies have demonstrated that biologic scaffolds are rich in latent growth factors, particularly basic fibroblast growth factor (bFGF) and vascular endothelial growth factor (VEGF) which have been shown to be essential in the promotion of angiogenesis and constructive remodeling, particularly in the repair of skeletal muscle (Germani et al., 2003; Menetrey et al., 2000). The concentration of these growth factors within the biologic scaffolds can be altered by the methods used to prepare the material (Reing et al., 2010). Equally, variations in growth factor content can occur as a consequence of source animal age (Tottey et al., 2011b). Nonetheless, the significance of these growth factors in promoting constructive tissue remodeling is largely unknown as no studies exist where growth factors have been specifically depleted from these biologic materials. Potentially more important than overall growth factor content may be the distribution of these growth factors within the 3D architecture of the scaffold. Biologic scaffolds often possess anatomic site specificity; that is, their growth factor content and ultrastructural architecture are unique and specific to the source tissue from which they are derived. It may therefore be possible to tailor a biologic scaffold to maximize the constructive remodeling response. For example, growth factors such as hepatocyte growth factor (HGF) and insulin like growth factor-1 (IGF-1) are known to be critical for muscle growth and myoblast proliferation (Chakravarthy et al., 2001; Charge and Rudnicki, 2004; Hsu et al., 1997; Menetrey et al., 2000). HGF is a primary regulator of satellite cell proliferation (Allen et al., 1995; Gal-Levi et al., 1998; Li et al., 2009; Sheehan et al., 2000), with HGF expression increasing in proportion to the degree of injury (Suzuki et al., 2002; Tatsumi, 2010; Tatsumi et al., 2002). Thus, ECM derived from tissues rich in HGF, such as liver, may prove more beneficial to the skeletal muscle constructive remodeling response than ECM derived from tissues low in HGF.

The same proteases that degrade the remnant ECM of native tissue following injury are also responsible for degrading a surgically placed ECM scaffold. This degradation process releases small peptides, termed matricryptic peptides, which activate multiple cell surface receptors and alter the cellular response to tissue injury (Davis, 2010; Davis et al., 2000). Calve et al. (2010) demonstrated that ECM deposited during amphibian limb regeneration provided instructional cues for both myoblasts and satellite cells that are vital for muscle repair. Similarly, degradation products of ECM, generated by in vitro digestion, have been shown to have potent biologic effects including mitogenic and chemotactic effects on muscle progenitor cells (Crisan et al., 2009; Tottey et al., 2011a; Vorotnikova et al., 2010).

Biologic scaffolds have been successfully used to repair or replace a variety of damaged or diseased tissues, including cardiac (Akhyari et al., 2008; Badylak et al., 2006; Kochupura et al., 2005), esophageal (Nieponice et al., 2006; Nieponice et al., 2008), dermal (Brigido et al., 2004), and musculotendinous (Aurora et al., 2007; De Deyne and Kladakis, 2005; Dejardin et al., 2001; Snyder et al., 2009) tissues, among others.

In the context of skeletal muscle repair, Conconni et al. (2005) have shown benefits using decellularized abdominal muscle seeded with cultured myoblasts. This group showed that, when implanted in the abdominal wall location, these constructs generated a complex skeletal muscle tissue that was contractile and vascularized within 9 days. Similarly, Merritt et al. (2010) have shown that a biologic scaffold seeded with bone marrow-derived stem cells can successfully regenerate lost muscle tissue in a mouse model of volumetric muscle loss in the quadriceps. In many cases, the acellular ECM alone is capable of restoring functional tissue without an additional cellular component. Valentin et al. (2010) showed that acellular ECM derived from small intestinal submucosa (SIS) induced almost complete replacement of the defect site with islands and sheets of skeletal muscle after 6 months in a rodent abdominal wall model. This new muscle generated $\sim 80 \%$ of the contractile force of native muscle (Valentin et al., 2010). Similarly, in a model of severe gastrocnemius muscle trauma with massive tissue loss, the implantation of SIS-ECM promoted the formation of vascularized skeletal muscle that was functionally innervated and almost indistinguishable to native muscle by 6 months (Turner et al., 2010). These findings have translated into the successful restoration 


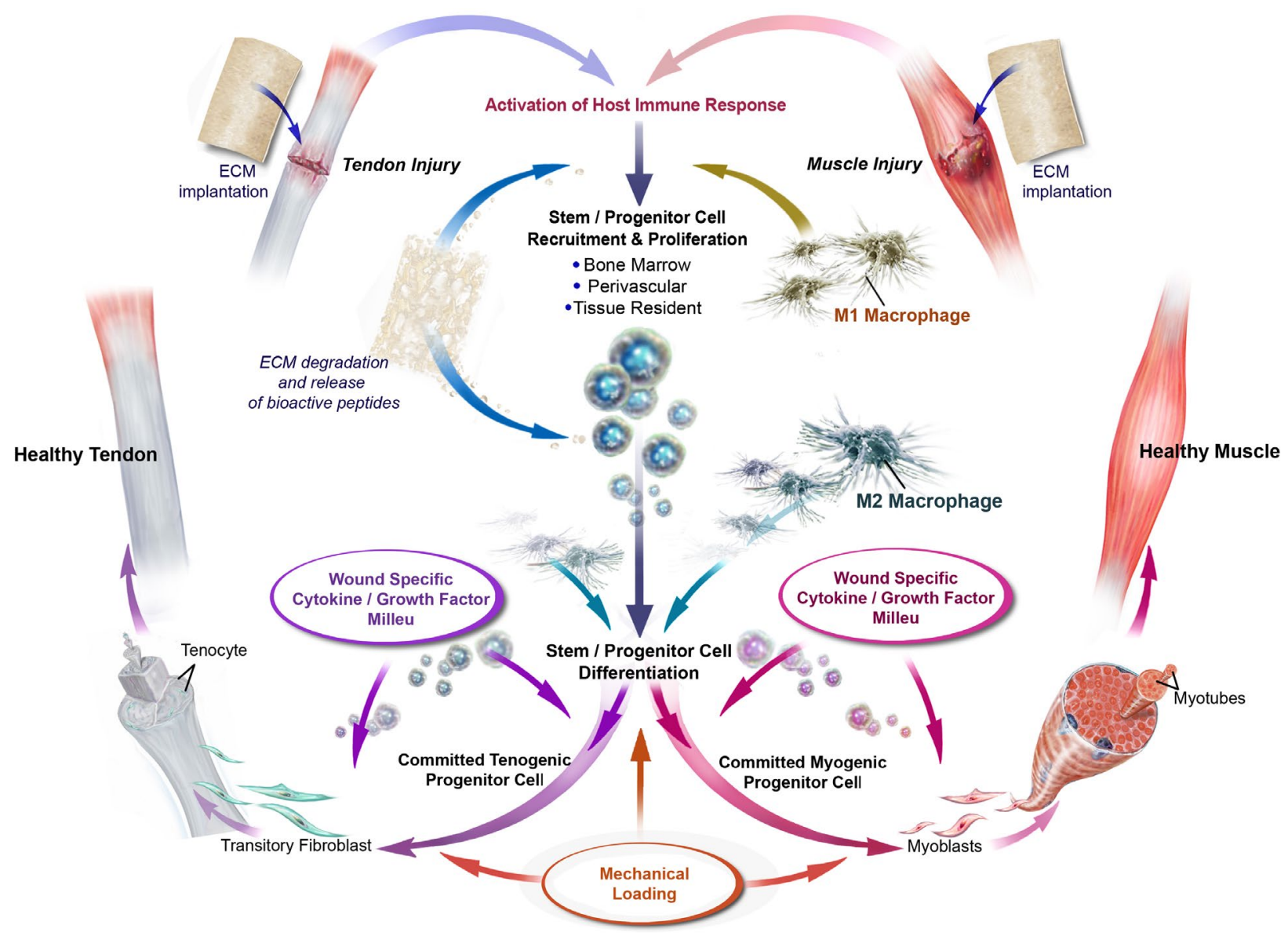

Fig. 2. Overview of ECM-mediated constructive remodeling of musculotendinous injuries. Implantation of a biologic scaffold modifies the host immune response and stimulates progenitor cell recruitment and differentiation. Woundspecific factors determine cell fate resulting in site-specific tissue remodeling.

of skeletal muscle in human patients that have suffered volumetric muscle loss. Mase et al. (2010) have shown that placement of an ECM scaffold in a large quadriceps muscle injury, where all previous treatments had proven unsuccessful, resulted in the restoration of new functional skeletal muscle and a significant increase in isokinetic performance.

\section{Stem and progenitor cells in biologic scaffold mediated musculotendinous repair}

As detailed in Fig. 2, the process of constructive tissue remodeling of either muscle or tendon tissue, which is induced by biologic scaffolds is complex and involves a number of factors including the unique wound microenvironment that defines the injury site. A key motivator of the constructive remodeling process is the recruitment, proliferation and differentiation of stem and progenitors cells elicited by the release of growth factors and degradation products from the biologic scaffolds. Following volumetric muscle loss, the proliferation of tissue resident cells and migration of circulating myogenic progenitor cells is particularly important and requires a cell population that is capable of sustained proliferation, self-renewal, myogenesis and resistance to oxidative or hypoxic stress. Perhaps the most obvious cell population to target is the muscle satellite cell (Cossu and Biressi, 2005; Jarvinen et al., 2005). However, these cells typically constitute only 1-3\% of total cells in skeletal muscle and in injuries with volumetric muscle-loss would be lost along with the excised tissue. A number of other myogenic stem cell populations have also been identified which are distinct from satellite cells, although the precise origin, identity and location of these cells remain speculative. These include myogenic progenitor cells characterized as CD56+, CD34-, CD144-, CD45- and CD146-; myo-endothelial cells characterized as CD56+, CD34+, CD144+, CD45and CD146-; perivascular progenitor cells characterized as CD56-, CD34-, CD144-, CD45- and CD146+; and a muscle-derived side population (MDSP) that has similar properties to hematopoietic stem cells in the bone marrow (Crisan et al., 2009; Deasy et al., 2004; Huard, 2008; Jankowski et al., 2002; Kallestad and McLoon, 2010; Lecourt et al., 2010; Peault et al., 2007; Qu-Petersen et al., 2002; Quintero et al., 2009; Ten Broek et al., 2010; Usas and Huard, 2007; Wu et al., 2010). The number of MDSCs increases rapidly following muscle trauma (Jackson et al., 2011; Nesti et al., 2008). Circulating CD133+ progenitor cells have also been identified with myogenic potential. 
Following severe muscle trauma with massive tissue loss, replacement of the defect with an ECM-scaffold resulted in the recruitment of CD133+ cells to the site of injury, which was associated with the formation of new skeletal muscle and blood vessels in the first 4 months following injury (Turner et al., 2010).

As an alternative strategy to in situ recruitment of cells, ECM has been commonly used as a delivery vehicle, where myogenic progenitor cells are seeded on a scaffold - which is then transferred to the in vivo site of interest (Beier et al., 2009; Borschel et al., 2004; Liao and Zhou, 2009; Merritt et al., 2010; Moon du et al., 2008; Vindigni et al., 2004). However, these techniques generally produce muscle tissue with minimal contractile forces since the amount of scaffold material is high and can inhibit myoblast fusion. Many approaches use a gel-based construct of mainly collagen, laminin or fibrin that do not necessarily replicate the complex ultrastructure of native tissue (Beier et al., 2009; Huang et al., 2005; Matsumoto et al., 2007; Rowlands et al., 2007; Vandenburgh et al., 1988).

The use of acellular biologic scaffolds which maintain the complex 3D ultrastructure of the native tissue represents an alternative approach. For example, a biologic scaffold derived from skeletal muscle tissue may retain endomysial tubes and remnant neural and vascular pathways that can promote myoblast alignment and fusion and stimulate neurovascular growth (Borschel et al., 2004; Di Benedetto et al., 1994; Gillies et al., 2011). In addition, the use of acellular scaffolds overcomes many of the hurdles associated with cell seeding, such as the necessity for prolonged in vitro cell culture, or the requirement for specific bioreactors that provide physiologic stimulation of the cells to promote differentiation.

\section{Biologic scaffolds in tendon repair}

Perhaps one of the most widespread clinical uses of biologic scaffolds is in the surgical repair of tendinous injuries (Aurora et al., 2007; Cheung et al., 2010; Derwin et al., 2010; Derwin et al., 2006). As detailed in Fig. 2, many processes in biologic scaffold-mediated skeletal muscle repair are also involved in biologic scaffoldmediated tendon injury repair. The complex cytokine and growth factor milieu, as well as the unique mechanical forces that define the two different injury sites, ultimately determine the differentiation pathway the infiltrating stem and progenitor cells will follow. Thus, the same biologic scaffold material can have the potential to promote both tendon and skeletal muscle repair, possibly within the same injury site (Turner et al., 2010). However, despite the growing clinical use of biologic scaffolds, there are still many questions related to their mechanism of action, surgical application and efficacy that remain unanswered. Repair of the rotator cuff with biologic scaffolds is well documented (Aurora et al., 2007; Cheung et al., 2010; Derwin et al., 2010; Iannotti et al., 2008; Tsiridis et al., 2008), but the use of biologic scaffolds in the repair of flexor tendons is rarely investigated (Derwin et al., 2004). In many cases, biologic scaffolds are primarily used as surgical meshes promoting strength and support rather than constructive tissue remodeling. As a result, biologic scaffolds for tendon repair tend to be either thick multilaminate devices or chemically cross-linked scaffolds manufactured to increase structural strength. As previously noted, these modifications can have significant negative effects on the host constructive remodeling response. There is a paucity of data on biologic scaffold-mediated constructive tissue remodeling in tendon.

Recent research has shown that just as degradation products and growth factors released by biologic scaffolds can promote stem and progenitor cells migration and proliferation in skeletal muscle, these bioactive molecules also enhance tendon healing in a similar way. Bi et al. (2007) have shown tendon contains a specific population of tendon progenitor cells that exist within an ECM niche. In addition, this group showed that this ECM niche controls tendon progenitor cell fate and speculated that alteration of the ECM composition signaled tenogenesis versus osteogenesis of the progenitor cells. Zantop et al. (2006) showed that the use of a biologic scaffold to repair an Achilles tendon defect promoted the migration of bone marrow-derived progenitor cells to the site of injury that adopted a tenocyte-like morphology. Mienaltowski et al. (2012) further characterized the progenitor cell niche in tendon, identifying a series of regional differences in progenitor cell distribution. Cells within the tendon tended to express Sca-1, CD90 and CD44, while progenitor cells in the peritendon region were more similar to perivascular progenitor cells expressing vascular and pericyte markers. Interestingly, many of these progenitor cell populations express similar surface markers to progenitor cell populations identified to be involved in skeletal muscle repair suggesting there may be a common progenitor cell pool within adult tissues.

The importance of macrophage phenotype in the promotion of tendon repair has also recently been highlighted. Dakin et al. (2012) investigated the contribution of different macrophage phenotypes to tendon healing showing that while the M1 phenotype predominated in sub-acute tendon injuries, there was a switch towards an M2 phenotype with chronic injuries. However, while further work is required to characterize the macrophage response and its contribution to tendon healing, it is possible that, as in skeletal muscle injuries, biologic scaffolds may modulate phenotypic switching of macrophages.

Tendon injuries are among the most common musculoskeletal problems affecting the adult population. More than $50 \%$ of individuals over the age of 80 experience rotator cuff injury requiring surgical repair (Longo et al., 2012; Tempelhof et al., 1999). In the USA every year, $11 \%$ of runners will suffer from Achilles tendon injuries (Kaz et al., 2007; Rees et al., 2006). Incomplete healing of tendon injuries can lead to compromised function and pain requiring surgical intervention. Surgical intervention, particularly of large tendon pathology, can be problematic and frequently involves the repair of degenerating tendon tissue that may be unable to sustain the forces associated with activities of daily living and will never regain the strength of the uninjured tendon, which increases the risk of repeated injury. Tendon augmentation 
with a biologic scaffold material provides an alternative approach to autografts, xenografts and tendon prostheses and overcomes the problem of limited donor tissue.

Rotator cuff tears are a common source of shoulder pain with an incidence in the general population of up to $27 \%$ and $37 \%$ for full and partial tears, respectively (Itoi et al., 1995; Yamanaka and Matsumoto, 1994). Despite surgical intervention there is a high rate of recurrent injury (Aurora et al., 2007; Conti et al., 2009; Iannotti et al., 2006; Longo et al., 2012; Soler et al., 2007; Walton et al., 2007), particularly in multi tendon rotator cuff tears. Consequently, the use of biologic scaffold materials for rotator cuff repair has increased with the hope that ECM scaffolds can provide temporary mechanical support while also promoting host remodeling and improved tissue remodeling.

The most commonly used biologic scaffolds for rotator cuff repair include Graftjacket ${ }^{\circledR}$, Restore ${ }^{\mathrm{TM}}$, Cuffpatch $^{\mathrm{TM}}$, TissueMend $^{\circledR}$ and OrthADAPT ${ }^{\mathrm{TM}}$. These devices represent a range of source tissues including dermis, small intestinal submucosa and pericardium. In addition, processing/ manufacturing of these biologic scaffolds often includes chemical cross-linking, lamination or lyophylization (or some combination thereof). As a result, remodeling responses for these biologic scaffolds vary considerably (Valentin et al., 2006) and clinical results range from success to abject failure (Fini et al., 2007; Walton et al., 2007).

The Restore ${ }^{\mathrm{TM}}$ device, composed of small intestinal submucosa, was the first commercially available biologic scaffold. Several preclinical studies demonstrated the efficacy of Restore ${ }^{\mathrm{TM}}$ in rotator cuff tendon repair. Dejardin et al. (2001) showed that SIS-ECM used in repairing a canine infraspinatus injury was completely replaced within 6 months by organized connective tissue similar to native tendon. Similar studies in the rabbit and rat also demonstrated the replacement of the SIS-ECM with organized collagenous tissue with superior biomechanical properties to unrepaired control groups (Chen et al., 2007; Perry et al., 2007; Zalavras et al., 2006; Zheng et al., 2005). Early clinical studies also suggested that Restore $^{\mathrm{TM}}$ showed successful rotator cuff reconstruction with post-operative follow up over a two-year period showing thickening of the cuff tendon and incorporation of the scaffolds in 11 out of 12 patients and improved functionality (Metcalf et al., 2002). However, subsequent studies suggested that Restore ${ }^{\mathrm{TM}}$ does not improve the rate of tendon healing and may be associated with a high rate of recurrent rupture. Sclamberg et al. (2004) showed that 6 months postoperatively 10 or 11 patients had failed repairs. Other investigators have shown that unaugmented groups perform equally or better than those treated with Restore (Walton et al., 2007; Iannotti et al., 2006). In the majority of these reports the major reported side effect was a non-infectious, sterile effusion. Given the success of SIS-ECM scaffolds in pre-clinical studies and in other body sites, the reasons for this high failure rate are not entirely clear. It is known that site-specific changes in the wound microenvironment, including extent of injury, post operative NSAID use and post-operative rehabilitation
(Galatz et al., 2009; Galatz et al., 2001; Iannotti, 1994; Longo et al., 2012; Maffulli et al., 2011; Tanaka et al., 2010) have dramatic effects on constructive remodeling. In addition, the recruitment of progenitor cells, modulation of the innate immune response and generation of bioactive cryptic peptides over a period of weeks to months have known effects on the clinical symptoms of patients.

Other biologic scaffolds have shown greater success. Graftjacket $^{\circledR}$, derived from human dermis, has shown efficacy in a number of studies. Adams et al. (2006) showed that use of Graftjacket ${ }^{\circledR}$ as an interpositional graft in the canine infraspinatus injury model results in a robust tendon-like tissue formed at the site of implantation within 6 months. A number of groups have shown positive outcomes using Graftjacket ${ }^{\circledR}$ for interpositional repair of large rotator cuff tears in human patients (Bond et al., 2008; Rotini et al., 2011; Snyder et al., 2009). Significant improvement in mobility and a reported decrease in pain were reported (Bond et al., 2008).

The paucity of controlled comparison studies using biologic scaffolds for rotator cuff repair makes it difficult to define indications for their respective use. However, it is clear that biologic scaffolds are best suited to situations where a poor healing outcome is likely, such as chronic and/or large rotator cuff tears. Data on the repair of other tendon injuries is limited, particularly in flexor tendon repair. However, a number of studies have shown biologic scaffolds to have efficacy in Achilles tendon repair.

In a canine model of Achilles tendon repair, it was shown that SIS-ECM scaffolds remodeled into neotendon that had organized collagenous architecture similar to normal healthy tendon, which was stronger than either the musculotendinous origin or boney insertion (Badylak et al., 1995). Later studies showed the contribution of bone marrow-derived cells to long term remodeling of SISECM in Achilles tendon repair (Zantop et al., 2006). More recently, the ability of SIS-ECM scaffolds to promote the formation of a new, functional musculotendinous origin between the Achilles tendon and gastrocnemius muscle has been shown (Turner et al., 2010). A lack of clinical data makes it difficult to determine whether these preclinical successes translate to successful tendon repair in humans. A number of clinical studies do exist which have evaluated Graftjacket ${ }^{\circledR}$ in the repair of Achilles tendon rupture (Branch, 2011; Lee, 2008; Lee, 2004; Liden and Simmons, 2009). Graftjacket ${ }^{\circledR}$ is reported to have the strongest mechanical properties among five other commercially available scaffolds for tendon repair. In a human cadaver model, Barber et al. (2006) showed that Graftjacket ${ }^{\circledR}$ significantly increased Achilles tendon strength and stiffness. In a series of clinical studies Lee et al. $(2004 ; 2008)$ showed that repair of Achilles tendon rupture with Graftjacket ${ }^{\circledR}$ resulted in an early return to activity and good plantar flexion strength with no reruptures of chronic pain up to 30 months post-operatively.

It is important to note that all xenogeneic biologic scaffolds are approved by the FDA only for the reinforcement of soft tissues and not as interpositional grafts intended to replace normal body structure or function. As our understanding of biologic scaffolds 
increases and the mechanism(s) with which they interact with the wound microenvironment becomes known, their constructive use will undoubtedly expand.

\section{Conclusion}

The use of biologic scaffolds for musculotendinous tissue reconstruction in the context of regenerative medicine represents a fundamentally different strategy from traditional surgical approaches. While their clinical use continues to increase, it is clear that a greater understanding of the biochemical, cellular and mechanical cues that stimulate the constructive remodeling response is required. Biologic scaffolds are known to promote the migration and proliferation of progenitor cells when implanted in an injury site. However, many questions remain as to the cues that cause these cells to then differentiate into site appropriate tissue, Future directions in developing the use of biologic scaffolds and/or the promotion of constructive tissue remodeling may focus on the importance of mechanical loading and physiologic stimulation on cell differentiation. In addition, further characterization of the composition of biologic scaffolds derived from different tissues may identify biologic scaffolds that provide superior constructive remodeling in certain injury sites. Similarly, an improved understanding of the methods of biologic scaffold preparation may provide further insight into the retention and release of growth factors and the generation of matricryptic peptides from these materials leading to improved clinical outcomes.

\section{Acknowledgements}

We wish to confirm that there are no known conflicts of interest associated with this publication and there has been no significant financial support for this work that could have influenced its outcome.

\section{References}

Aarimaa V, Kaariainen M, Vaittinen S, Tanner J, Jarvinen T, Best T, Kalimo H (2004) Restoration of myofiber continuity after transection injury in the rat soleus. Neuromuscul Disord 14: 421-428.

Adams JE, Zobitz ME, Reach JS, Jr., An KN, Steinmann SP (2006) Rotator cuff repair using an acellular dermal matrix graft: an in vivo study in a canine model. Arthroscopy 22: 700-709.

Akhyari P, Kamiya H, Haverich A, Karck M, Lichtenberg A (2008) Myocardial tissue engineering: the extracellular matrix. Eur J Cardiothorac Surg 34: 229-241.

Al-Shanti N, Saini A, Faulkner SH, Stewart CE (2008) Beneficial synergistic interactions of TNF-alpha and IL-6 in C2 skeletal myoblasts - potential cross-talk with IGF system. Growth Factors 26: 61-73.

Allen RE, Sheehan SM, Taylor RG, Kendall TL, Rice GM (1995) Hepatocyte growth factor activates quiescent skeletal muscle satellite cells in vitro. J Cell Physiol 165: 307-312.

Ariganello MB, Labow RS, Lee JM (2010) In vitro response of monocyte-derived macrophages to a decellularized pericardial biomaterial. J Biomed Mater Res A 93: 280-288.

Ariganello MB, Simionescu DT, Labow RS, Lee JM (2011) Macrophage differentiation and polarization on a decellularized pericardial biomaterial. Biomaterials 32: 439-449.

Aurora A, McCarron J, Iannotti JP, Derwin K (2007) Commercially available extracellular matrix materials for rotator cuff repairs: state of the art and future trends. J Shoulder Elbow Surg 16: S171-178.

Badylak SF (2007) The extracellular matrix as a biologic scaffold material. Biomaterials 28: 3587-3593.

Badylak SF, Tullius R, Kokini K, Shelbourne KD, Klootwyk T, Voytik SL, Kraine MR, Simmons C (1995) The use of xenogeneic small intestinal submucosa as a biomaterial for Achilles tendon repair in a dog model. $\mathrm{J}$ Biomed Mater Res 29: 977-985.

Badylak SF, Kochupura PV, Cohen IS, Doronin SV, Saltman AE, Gilbert TW, Kelly DJ, Ignotz RA, Gaudette GR (2006) The use of extracellular matrix as an inductive scaffold for the partial replacement of functional myocardium. Cell Transplant 15 Suppl 1: S29-40.

Badylak SF, Valentin JE, Ravindra AK, McCabe GP, Stewart-Akers AM (2008) Macrophage phenotype as a determinant of biologic scaffold remodeling. Tissue Eng Part A 14: 1835-1842.

Badylak SF, Brown BN, Gilbert TW, Daly KA, Huber A, Turner NJ (2011) Biologic scaffolds for constructive tissue remodeling. Biomaterials 32: 316-319.

Barber FA, Herbert MA, Coons DA (2006) Tendon augmentation grafts: biomechanical failure loads and failure patterns. Arthroscopy 22: 534-538.

Beier JP, Klumpp D, Rudisile M, Dersch R, Wendorff JH, Bleiziffer O, Arkudas A, Polykandriotis E, Horch RE, Kneser U (2009) Collagen matrices from sponge to nano: new perspectives for tissue engineering of skeletal muscle. BMC Biotechnol 9: 34.

Beiner JM, Jokl P (2001) Muscle contusion injuries: current treatment options. J Am Acad Orthop Surg 9: 227237.

Bi Y, Ehirchiou D, Kilts TM, Inkson CA, Embree MC, Sonoyama W, Li L, Leet AI, Seo BM, Zhang L, Shi S, Young MF (2007) Identification of tendon stem/progenitor cells and the role of the extracellular matrix in their niche. Nat Med 13: 1219-1227.

Bond JL, Dopirak RM, Higgins J, Burns J, Snyder SJ (2008) Arthroscopic replacement of massive, irreparable rotator cuff tears using a GraftJacket allograft: technique and preliminary results. Arthroscopy 24: 403-409.

Borschel GH, Dennis RG, Kuzon WM, Jr. (2004) Contractile skeletal muscle tissue-engineered on an acellular scaffold. Plast Reconstr Surg 113: 595-602.

Branch JP (2011) A tendon graft weave using an acellular dermal matrix for repair of the Achilles tendon and other foot and ankle tendons. J Foot Ankle Surg 50: 257-265. 
Brigido SA, Boc SF, Lopez RC (2004) Effective management of major lower extremity wounds using an acellular regenerative tissue matrix: A pilot study. Orthopedics 27: S145-S149.

Brown BN, Valentin JE, Stewart-Akers AM, McCabe GP, Badylak SF (2009) Macrophage phenotype and remodeling outcomes in response to biologic scaffolds with and without a cellular component. Biomaterials 30: 1482-1491.

Calve S, Odelberg SJ, Simon HG (2010) A transitional extracellular matrix instructs cell behavior during muscle regeneration. Dev Biol 344: 259-271.

Chakravarthy MV, Booth FW, Spangenburg EE (2001) The molecular responses of skeletal muscle satellite cells to continuous expression of IGF-1: implications for the rescue of induced muscular atrophy in aged rats. Int J Sport Nutr Exerc Metab 11 Suppl: S44-48.

Charge SB, Rudnicki MA (2004) Cellular and molecular regulation of muscle regeneration. Physiol Rev 84: 209-238.

Chen SE, Gerken E, Zhang Y, Zhan M, Mohan RK, Li AS, Reid MB, Li YP (2005) Role of TNF-\{alpha\} signaling in regeneration of cardiotoxin-injured muscle. Am J Physiol Cell Physiol 289: C1179-1187.

Chen JM, Willers C, Xu J, Wang A, Zheng MH (2007) Autologous tenocyte therapy using porcine-derived bioscaffolds for massive rotator cuff defect in rabbits. Tissue Eng 13: 1479-1491.

Cheung EV, Silverio L, Sperling JW (2010) Strategies in biologic augmentation of rotator cuff repair: a review. Clin Orthop Relat Res 468: 1476-1484.

Conconi MT, De Coppi P, Bellini S, Zara G, Sabatti M, Marzaro M, Zanon GF, Gamba PG, Parnigotto PP, Nussdorfer GG (2005) Homologous muscle acellular matrix seeded with autologous myoblasts as a tissueengineering approach to abdominal wall-defect repair. Biomaterials 26: 2567-2574.

Conti M, Garofalo R, Delle Rose G, Massazza G, Vinci E, Randelli M, Castagna A (2009) Post-operative rehabilitation after surgical repair of the rotator cuff. Chir Organi Mov 93 Suppl 1: S55-63.

Corona BT, Machingal MA, Criswell T, Vadhavkar M, Dannahower AC, Bergman C, Zhao W, Christ GJ (2012) Further development of a tissue engineered muscle repair construct in vitro for enhanced functional recovery following implantation in vivo in a murine model of volumetric muscle loss injury. Tissue Eng Part A 18: 1213 1228.

Cossu G, Biressi S (2005) Satellite cells, myoblasts and other occasional myogenic progenitors: possible origin, phenotypic features and role in muscle regeneration. Semin Cell Dev Biol 16: 623-631.

Counsel P, Breidahl W (2010) Muscle injuries of the lower leg. Semin Musculoskelet Radiol 14: 162-175.

Crisan M, Chen CW, Corselli M, Andriolo G, Lazzari L, Peault B (2009) Perivascular multipotent progenitor cells in human organs. Ann N Y Acad Sci 1176: 118-123.

Crow BD, Haltom JD, Carson WL, Greene WB, Cook JL (2007) Evaluation of a novel biomaterial for intrasubstance muscle laceration repair. J Orthop Res 25: 396-403.
Dakin SG, Werling D, Hibbert A, Abayasekara DR, Young NJ, Smith RK, Dudhia J (2012) Macrophage subpopulations and the lipoxin A4 receptor implicate active inflammation during equine tendon repair. PLoS One 7: e32333.

Daly KA, Wolf M, Johnson SA, Badylak SF (2011) A rabbit model of peripheral compartment syndrome with associated rhabdomyolysis and a regenerative medicine approach for treatment. Tissue Eng Part C Methods 17: 631-640.

Davis GE (2010) Matricryptic sites control tissue injury responses in the cardiovascular system: relationships to pattern recognition receptor regulated events. J Mol Cell Cardiol 48: 454-460.

Davis GE, Bayless KJ, Davis MJ, Meininger GA (2000) Regulation of tissue injury responses by the exposure of matricryptic sites within extracellular matrix molecules. Am J Pathol 156: 1489-1498.

De Deyne PG, Kladakis SM (2005) Bioscaffolds in tissue engineering: a rationale for use in the reconstruction of musculoskeletal soft tissues. Clin Podiatr Med Surg 22: 521-532.

Deasy BM, Li Y, Huard J (2004) Tissue engineering with muscle-derived stem cells. Curr Opin Biotechnol 15: 419-423.

Dejardin LM, Arnoczky SP, Ewers BJ, Haut RC, Clarke RB (2001) Tissue-engineered rotator cuff tendon using porcine small intestine submucosa. Histologic and mechanical evaluation in dogs. Am J Sports Med 29: $175-$ 184.

Delavary BM, van der Veer WM, van Egmond M, Niessen FB, Beelen RH (2011) Macrophages in skin injury and repair. Immunobiology 216: 753-762.

Derwin K, Androjna C, Spencer E, Safran O, Bauer TW, Hunt T, Caplan A, Iannotti J (2004) Porcine small intestine submucosa as a flexor tendon graft. Clin Orthop Relat Res 423: 245-252.

Derwin KA, Baker AR, Spragg RK, Leigh DR, Iannotti JP (2006) Commercial extracellular matrix scaffolds for rotator cuff tendon repair. Biomechanical, biochemical, and cellular properties. J Bone Joint Surg Am 88A: 2665-2672.

Derwin KA, Badylak SF, Steinmann SP, Iannotti JP (2010) Extracellular matrix scaffold devices for rotator cuff repair. J Shoulder Elbow Surg 19: 467-476.

Di Benedetto G, Lassner F, Riccio M, Pugnaloni A, Tappa MM, Biagini G, Berger A, Bertani A (1994) The use of acellular autologous skeletal muscle grafts in peripheral nerve repair: a morphometrical-morphological study. Clin Mater 16: 137-143.

Fini M, Torricelli P, Giavaresi G, Rotini R, Castagna A, Giardino R (2007) In vitro study comparing two collageneous membranes in view of their clinical application for rotator cuff tendon regeneration. J Orthop Res 25: 98-107.

Fleming BD, Mosser DM (2011) Regulatory macrophages: setting the threshold for therapy. Eur $\mathrm{J}$ Immunol 41: 2498-2502.

Gal-Levi R, Leshem Y, Aoki S, Nakamura T, Halevy O (1998) Hepatocyte growth factor plays a dual role in regulating skeletal muscle satellite cell proliferation and differentiation. Biochim Biophys Acta 1402: 39-51. 
Galatz LM, Griggs S, Cameron BD, Iannotti JP (2001) Prospective longitudinal analysis of postoperative shoulder function: a ten-year follow-up study of full-thickness rotator cuff tears. J Bone Joint Surg Am 83A: 1052-1056.

Galatz LM, Charlton N, Das R, Kim HM, Havlioglu N, Thomopoulos S (2009) Complete removal of load is detrimental to rotator cuff healing. J Shoulder Elbow Surg 18: 669-675.

Gamba PG, Conconi MT, Lo Piccolo R, Zara G, Spinazzi R, Parnigotto PP (2002) Experimental abdominal wall defect repaired with acellular matrix. Pediatr Surg Int 18: $327-331$.

Garrett WE, Jr. (1996) Muscle strain injuries. Am J Sports Med 24: S2-8.

Garrett WE, Jr., Seaber AV, Boswick J, Urbaniak JR, Goldner JL (1984) Recovery of skeletal muscle after laceration and repair. J Hand Surg Am 9: 683-692.

Germani A, Di Carlo A, Mangoni A, Straino S, Giacinti C, Turrini P, Biglioli P, Capogrossi MC (2003) Vascular endothelial growth factor modulates skeletal myoblast function. Am J Pathol 163: 1417-1428.

Gillies AR, Smith LR, Lieber RL, Varghese S (2011) Method for decellularizing skeletal muscle without detergents or proteolytic enzymes. Tissue Eng Part C Methods 17: 383-389.

Gurtner GC, Werner S, Barrandon Y, Longaker MT (2008) Wound repair and regeneration. Nature 453: 314 321.

Hayashi S, Aso H, Watanabe K, Nara H, Rose MT, Ohwada S, Yamaguchi T (2004) Sequence of IGF-I, IGFII, and HGF expression in regenerating skeletal muscle. Histochem Cell Biol 122: 427-434.

Hsu HH, Zdanowicz MM, Agarwal VR, Speiser PW (1997) Expression of myogenic regulatory factors in normal and dystrophic mice: effects of IGF-1 treatment. Biochem Mol Med 60: 142-148.

Huang YC, Dennis RG, Larkin L, Baar K (2005) Rapid formation of functional muscle in vitro using fibrin gels. J Appl Physiol 98: 706-713.

Huard J (2008) Regenerative medicine based on muscle stem cells. J Musculoskelet Neuronal Interact 8: 337.

Huard J, Li Y, Fu FH (2002) Muscle injuries and repair: current trends in research. J Bone Joint Surg Am 84-A: 822-832.

Iannotti JP (1994) Full-thickness rotator cuff tears: factors affecting surgical outcome. J Am Acad Orthop Surg 2: 87-95.

Iannotti JP, Codsi MJ, Kwon YW, Derwin K, Ciccone J, Brems JJ (2006) Porcine small intestine submucosa augmentation of surgical repair of chronic two-tendon rotator cuff tears. A randomized, controlled trial. J Bone Joint Surg Am 88: 1238-1244.

Iannotti JP, DeFranco MJ, Codsi MJ, Maschke SD, Derwin KA (2008) Natural extracellular matrix grafts for rotator cuff repair. In: Abrams JS, Bell RH (eds) Arthroscopic Rotator Cuff Surgery : A Practical Approach to Management, Springer Science, New York, pp 246-268.

Itoi E, Berglund LJ, Grabowski JJ, Schultz FM, Growney ES, Morrey BF, An KN (1995) Tensile properties of the supraspinatus tendon. J Orthop Res 13: 578-584.
Jackson WM, Lozito T, Djouad F, Kuhn NZ, Nesti LJ, Tuan RS (2011) Differentiation and regeneration potential of mesenchymal progenitor cells derived from traumatized muscle tissue. J Cell Mol Med 15: 2377-2388.

Jankowski RJ, Deasy BM, Huard J (2002) Musclederived stem cells. Gene Ther 9: 642-647.

Jarvinen TA, Kaariainen M, Jarvinen M, Kalimo H (2000) Muscle strain injuries. Curr Opin Rheumatol 12: 155-161.

Jarvinen TA, Jarvinen TL, Kaariainen M, Kalimo H, Jarvinen M (2005) Muscle injuries: biology and treatment. Am J Sports Med 33: 745-764.

Jensen LT, Host NB (1997) Collagen: scaffold for repair or execution. Cardiovasc Res 33: 535-539.

Kallestad KM, McLoon LK (2010) Defining the heterogeneity of skeletal muscle-derived side and main population cells isolated immediately ex vivo. J Cell Physiol 222: 676-684.

Kaz R, Starman JS, Fu FH (2007) Anatomic doublebundle anterior cruciate ligament reconstruction revision surgery. Arthroscopy 23: 1250 e1-3.

Keane TJ, Londono R, Turner NJ, Badylak SF (2012) Consequences of ineffective decellularization of biologic scaffolds on the host response. Biomaterials 33: 1771-1781.

Kin S, Hagiwara A, Nakase Y, Kuriu Y, Nakashima S, Yoshikawa T, Sakakura C, Otsuji E, Nakamura T, Yamagishi H (2007) Regeneration of skeletal muscle using in situ tissue engineering on an acellular collagen sponge scaffold in a rabbit model. ASAIO J 53: 506-513.

Kochupura PV, Azeloglu EU, Kelly DJ, Doronin SV, Badylak SF, Krukenkamp IB, Cohen IS, Gaudette GR (2005) Tissue-engineered myocardial patch derived from extracellular matrix provides regional mechanical function. Circulation 112: I144-149.

Kresse H, Schonherr E (2001) Proteoglycans of the extracellular matrix and growth control. J Cell Physiol 189: 266-274.

Lecourt S, Marolleau JP, Fromigue O, Vauchez K, Andriamanalijaona R, Ternaux B, Lacassagne MN, Robert I, Boumediene K, Chereau F, Marie P, Larghero J, Fiszman M, Vilquin JT (2010) Characterization of distinct mesenchymal-like cell populations from human skeletal muscle in situ and in vitro. Exp Cell Res 316: 2513-2526.

Lee MS (2004) GraftJacket augmentation of chronic Achilles tendon ruptures. Orthopedics 27: S151-153.

Lee DK (2008) A preliminary study on the effects of acellular tissue graft augmentation in acute Achilles tendon ruptures. J Foot Ankle Surg 47: 8-12.

Lehto MU, Jarvinen MJ (1991) Muscle injuries, their healing process and treatment. Ann Chir Gynaecol 80: 102-108.

Li J, Reed SA, Johnson SE (2009) Hepatocyte growth factor (HGF) signals through SHP2 to regulate primary mouse myoblast proliferation. Exp Cell Res 315: 22842292.

Liao H, Zhou GQ (2009) Development and progress of engineering of skeletal muscle tissue. Tissue Eng Part B Rev 15: 319-331.

Liden BA, Simmons M (2009) Histologic evaluation of a 6-month GraftJacket matrix biopsy used for Achilles 
tendon augmentation. J Am Podiatr Med Assoc 99: 104107.

Lolmede K, Campana L, Vezzoli M, Bosurgi L, Tonlorenzi R, Clementi E, Bianchi ME, Cossu G, Manfredi AA, Brunelli S, Rovere-Querini P (2009) Inflammatory and alternatively activated human macrophages attract vesselassociated stem cells, relying on separate HMGB1- and MMP-9-dependent pathways. J Leukoc Biol 85: 779-787.

Longo UG, Berton A, Papapietro N, Maffulli N, Denaro V (2012) Epidemiology, genetics and biological factors of rotator cuff tears. Med Sport Sci 57: 1-9.

Machingal MA, Corona BT, Walters TJ, Kesireddy V, Koval CN, Dannahower A, Zhao W, Yoo JJ, Christ GJ (2011) A tissue-engineered muscle repair construct for functional restoration of an irrecoverable muscle injury in a murine model. Tissue Eng Part A 17: 2291-2303.

Maffulli N, Longo UG, Berton A, Loppini M, Denaro $\mathrm{V}$ (2011) Biological factors in the pathogenesis of rotator cuff tears. Sports Med Arthrosc 19: 194-201.

Martinez FO, Sica A, Mantovani A, Locati M (2008) Macrophage activation and polarization. Front Biosci 13: 453-461.

Mase VJ, Jr., Hsu JR, Wolf SE, Wenke JC, Baer DG, Owens J, Badylak SF, Walters TJ (2010) Clinical application of an acellular biologic scaffold for surgical repair of a large, traumatic quadriceps femoris muscle defect. Orthopedics 33: 511.

Matsumoto T, Sasaki J, Alsberg E, Egusa H, Yatani H, Sohmura T (2007) Three-dimensional cell and tissue patterning in a strained fibrin gel system. PLoS One 2: e1211.

Menetrey J, Kasemkijwattana C, Fu FH, Moreland MS, Huard J (1999) Suturing versus immobilization of a muscle laceration. A morphological and functional study in a mouse model. Am J Sports Med 27: 222-229.

Menetrey J, Kasemkijwattana C, Day CS, Bosch P, Vogt M, Fu FH, Moreland MS, Huard J (2000) Growth factors improve muscle healing in vivo. J Bone Joint Surg Br 82 : 131-137.

Merritt EK, Cannon MV, Hammers DW, Le LN, Gokhale R, Sarathy A, Song TJ, Tierney MT, Suggs LJ, Walters TJ, Farrar RP (2010) Repair of traumatic skeletal muscle injury with bone-marrow-derived mesenchymal stem cells seeded on extracellular matrix. Tissue Eng Part A 16: 2871-2881.

Metcalf M, Savoie F, Kellum B (2002) Surgical technique for xenograft (SIS) augmentation of rotator-cuff repairs. Oper Tech Orthop 12: 204-208.

Mienaltowski MJ, Adams SM, Birk DE (2012) Regional differences in stem cell/progenitor cell populations from the mouse achilles tendon. Tissue Eng Part A 19: 199-210.

Miura T, Kishioka Y, Wakamatsu J, Hattori A, Hennebry A, Berry CJ, Sharma M, Kambadur R, Nishimura T (2006) Decorin binds myostatin and modulates its activity to muscle cells. Biochem Biophys Res Commun 340: $675-$ 680.

Moon du G, Christ G, Stitzel JD, Atala A, Yoo JJ (2008) Cyclic mechanical preconditioning improves engineered muscle contraction. Tissue Eng Part A 14: 473-482.

Nesti LJ, Jackson WM, Shanti RM, Koehler SM, Aragon AB, Bailey JR, Sracic MK, Freedman BA, Giuliani
JR, Tuan RS (2008) Differentiation potential of multipotent progenitor cells derived from war-traumatized muscle tissue. J Bone Joint Surg Am 90: 2390-2398.

Nieponice A, Gilbert TW, Badylak SF (2006) Reinforcement of esophageal anastomoses with an extracellular matrix scaffold in a canine model. Ann Thorac Surg 82: 2050-2058.

Nieponice A, McGrath K, Qureshi I, Beckman EJ, Luketich JD, Gilbert TW, Badylak SF (2008) An extracellular matrix scaffold for esophageal stricture prevention after circumferential EMR. Gastrointest Endosc 69: 289-296.

Owen SC, Shoichet MS (2010) Design of threedimensional biomimetic scaffolds. J Biomed Mater Res A 94: 1321-1331.

Peault B, Rudnicki M, Torrente Y, Cossu G, Tremblay JP, Partridge T, Gussoni E, Kunkel LM, Huard J (2007) Stem and progenitor cells in skeletal muscle development, maintenance, and therapy. Mol Ther 15: 867-877.

Perniconi B, Costa A, Aulino P, Teodori L, Adamo S, Coletti D (2011) The pro-myogenic environment provided by whole organ scale acellular scaffolds from skeletal muscle. Biomaterials 32: 7870-7882.

Perry SM, Gupta RR, Van Kleunen J, Ramsey ML, Soslowsky LJ, Glaser DL (2007) Use of small intestine submucosa in a rat model of acute and chronic rotator cuff tear. J Shoulder Elbow Surg 16: S179-183.

Ploeger DT, van Putten SM, Koerts JA, van Luyn MJ, Harmsen MC (2012) Human macrophages primed with angiogenic factors show dynamic plasticity, irrespective of extracellular matrix components. Immunobiology 217 : 299-306.

Qu-Petersen Z, Deasy B, Jankowski R, Ikezawa M, Cummins J, Pruchnic R, Mytinger J, Cao B, Gates C, Wernig A, Huard J (2002) Identification of a novel population of muscle stem cells in mice: potential for muscle regeneration. J Cell Biol 157: 851-864.

Quintero AJ, Wright VJ, Fu FH, Huard J (2009) Stem cells for the treatment of skeletal muscle injury. Clin Sports Med 28: 1-11.

Rees JD, Wilson AM, Wolman RL (2006) Current concepts in the management of tendon disorders. Rheumatology 45: 508-521.

Reing JE, Brown BN, Daly KA, Freund JM, Gilbert TW, Hsiong SX, Huber A, Kullas KE, Tottey S, Wolf MT, Badylak SF (2010) The effects of processing methods upon mechanical and biologic properties of porcine dermal extracellular matrix scaffolds. Biomaterials 31: 8626-8633.

Rieder E, Seebacher G, Kasimir MT, Eichmair E, Winter B, Dekan B, Wolner E, Simon P, Weigel G (2005) Tissue engineering of heart valves: decellularized porcine and human valve scaffolds differ importantly in residual potential to attract monocytic cells. Circulation 111: 27922797.

Robinson KA, Li J, Mathison M, Redkar A, Cui J, Chronos NA, Matheny RG, Badylak SF (2005) Extracellular matrix scaffold for cardiac repair. Circulation 112: I135-143.

Rotini R, Marinelli A, Guerra E, Bettelli G, Castagna A, Fini M, Bondioli E, Busacca M (2011) Human dermal matrix scaffold augmentation for large and massive rotator 
cuff repairs: preliminary clinical and MRI results at 1-year follow-up. Musculoskelet Surg 95 Suppl 1: S13-23.

Rowlands AS, Hudson JE, Cooper-White JJ (2007) From scrawny to brawny: the quest for neomusculogenesis; smart surfaces and scaffolds for muscle tissue engineering. Expert Rev Med Devices 4: 709-728.

Schmalbruch H (1976) The morphology of regeneration of skeletal muscles in the rat. Tissue Cell 8: 673-692.

Schultz GS, Wysocki A (2009) Interactions between extracellular matrix and growth factors in wound healing. Wound Repair Regen 17: 153-162.

Sclamberg SG, Tibone JE, Itamura JM, Kasraeian S (2004) Six-month magnetic resonance imaging follow-up of large and massive rotator cuff repairs reinforced with porcine small intestinal submucosa. J Shoulder Elbow Surg 13: $538-541$.

Sheehan SM, Tatsumi R, Temm-Grove CJ, Allen RE (2000) HGF is an autocrine growth factor for skeletal muscle satellite cells in vitro. Muscle Nerve 23: 239-245.

Sicari BM, Agrawal V, Siu BF, Medberry CJ, Dearth CL, Turner NJ, Badylak SF (2012) A murine model of volumetric muscle loss and a regenerative medicine approach for tissue replacement. Tissue Eng Part A 18: 1941-1948.

Silver FH, Pins G (1992) Cell growth on collagen: a review of tissue engineering using scaffolds containing extracellular matrix. J Long Term Eff Med Implants 2: 67-80.

Snyder SJ, Arnoczky SP, Bond JL, Dopirak R (2009) Histologic evaluation of a biopsy specimen obtained 3 months after rotator cuff augmentation with GraftJacket matrix. Arthroscopy 25: 329-333.

Soler JA, Gidwani S, Curtis MJ (2007) Early complications from the use of porcine dermal collagen implants (Permacol (TM)) as bridging constructs in the repair of massive rotator cuff tears - A report of 4 cases. Acta Orthop Belg 73: 432-436.

St Pierre BA, Tidball JG (1994) Macrophage activation and muscle remodeling at myotendinous junctions after modifications in muscle loading. Am J Pathol 145: 1463 1471.

Sun D, Martinez CO, Ochoa O, Ruiz-Willhite L, Bonilla JR, Centonze VE, Waite LL, Michalek JE, McManus LM, Shireman PK (2009) Bone marrow-derived cell regulation of skeletal muscle regeneration. FASEB J 23: 382-395.

Suzuki S, Yamanouchi K, Soeta C, Katakai Y, Harada R, Naito K, Tojo H (2002) Skeletal muscle injury induces hepatocyte growth factor expression in spleen. Biochem Biophys Res Commun 292: 709-714.

Szalay K, Razga Z, Duda E (1997) TNF inhibits myogenesis and downregulates the expression of myogenic regulatory factors myoD and myogenin. Eur J Cell Biol 74: 391-398.

Tanaka M, Itoi E, Sato K, Hamada J, Hitachi S, Tojo Y, Honda M, Tabata S (2010) Factors related to successful outcome of conservative treatment for rotator cuff tears. Ups J Med Sci 115: 193-200.

Tatsumi R (2010) Mechano-biology of skeletal muscle hypertrophy and regeneration: possible mechanism of stretch-induced activation of resident myogenic stem cells. Anim Sci J 81: 11-20.

Tatsumi R, Hattori A, Ikeuchi Y, Anderson JE, Allen RE (2002) Release of hepatocyte growth factor from mechanically stretched skeletal muscle satellite cells and role of $\mathrm{pH}$ and nitric oxide. Mol Biol Cell 13: 2909-2918.

Tedesco FS, Dellavalle A, Diaz-Manera J, Messina G, Cossu G (2010) Repairing skeletal muscle: regenerative potential of skeletal muscle stem cells. J Clin Invest 120: 11-19.

Tempelhof S, Rupp S, Seil R (1999) Age-related prevalence of rotator cuff tears in asymptomatic shoulders. J Shoulder Elbow Surg 8: 296-299.

Ten Broek RW, Grefte S, Von den Hoff JW (2010) Regulatory factors and cell populations involved in skeletal muscle regeneration. J Cell Physiol 224: 7-16.

Terada N, Takayama S, Yamada H, Seki T (2001) Muscle repair after a transsection injury with development of a gap: an experimental study in rats. Scand J Plast Reconstr Surg Hand Surg 35: 233-238.

Tesch PA, von Walden F, Gustafsson T, Linnehan RM, Trappe TA (2008) Skeletal muscle proteolysis in response to short-term unloading in humans. J Appl Physiol 105: 902-906.

Tidball JG (2005) Inflammatory processes in muscle injury and repair. Am J Physiol Regul Integr Comp Physiol 288: R345-353.

Tidball JG, Villalta SA (2010) Regulatory interactions between muscle and the immune system during muscle regeneration. Am J Physiol Regul Integr Comp Physiol 298: R1173-1187.

Tidball JG, Wehling-Henricks M (2007) Macrophages promote muscle membrane repair and muscle fibre growth and regeneration during modified muscle loading in mice in vivo. J Physiol 578: 327-336.

Torrente Y, El Fahime E, Caron NJ, Del Bo R, Belicchi M, Pisati F, Tremblay JP, Bresolin N (2003) Tumor necrosis factor-alpha (TNF-alpha) stimulates chemotactic response in mouse myogenic cells. Cell Transplant 12: 91-100.

Tottey S, Corselli M, Jeffries EM, Londono R, Peault B, Badylak SF (2011a) Extracellular matrix degradation products and low-oxygen conditions enhance the regenerative potential of perivascular stem cells. Tissue Eng Part A 17: 37-44.

Tottey S, Johnson SA, Crapo PM, Reing JE, Zhang L, Jiang H, Medberry CJ, Reines B, Badylak SF (2011b) The effect of source animal age upon extracellular matrix scaffold properties. Biomaterials 32: 128-136.

Tsiridis E, Velonis S, Limb D, Giannoudis PV (2008) Tissue engineering approaches to rotator cuff tendon deficiency. Connect Tissue Res 49: 455-463.

Tsujinaka T, Fujita J, Ebisui C, Yano M, Kominami E, Suzuki K, Tanaka K, Katsume A, Ohsugi Y, Shiozaki H, Monden M (1996) Interleukin 6 receptor antibody inhibits muscle atrophy and modulates proteolytic systems in interleukin 6 transgenic mice. J Clin Invest 97: 244-249.

Turner NJ, Yates AJ, Jr., Weber DJ, Qureshi IR, Stolz DB, Gilbert TW, Badylak SF (2010) Xenogeneic extracellular matrix as an inductive scaffold for regeneration 
of a functioning musculotendinous junction. Tissue Eng Part A 16: 3309-3317.

Turner NJ, Badylak JS, Weber DJ, Badylak SF (2012) Biologic scaffold remodeling in a dog model of complex musculoskeletal injury. J Surg Res 176: 490-502.

Usas A, Huard J (2007) Muscle-derived stem cells for tissue engineering and regenerative therapy. Biomaterials 28: 5401-5406.

Valentin JE, Badylak JS, McCabe GP, Badylak SF (2006) Extracellular matrix bioscaffolds for orthopaedic applications. A comparative histologic study. J Bone Joint Surg Am 88: 2673-2686.

Valentin JE, Stewart-Akers AM, Gilbert TW, Badylak SF (2009) Macrophage participation in the degradation and remodeling of extracellular matrix scaffolds. Tissue Eng Part A 15: 1687-1694.

Valentin JE, Turner NJ, Gilbert TW, Badylak SF (2010) Functional skeletal muscle formation with a biologic scaffold. Biomaterials 31: 7475-7484.

Vandenburgh HH, Karlisch P, Farr L (1988) Maintenance of highly contractile tissue-cultured avian skeletal myotubes in collagen gel. In Vitro Cell Dev Biol 24: 166-174.

Vindigni V, Mazzoleni F, Rossini K, Fabbian M, Zanin ME, Bassetto F, Carraro U (2004) Reconstruction of ablated rat rectus abdominis by muscle regeneration. Plast Reconstr Surg 114: 1509-1515.

Vorotnikova E, McIntosh D, Dewilde A, Zhang J, Reing JE, Zhang L, Cordero K, Bedelbaeva K, Gourevitch D, Heber-Katz E, Badylak SF, Braunhut SJ (2010) Extracellular matrix-derived products modulate endothelial and progenitor cell migration and proliferation in vitro and stimulate regenerative healing in vivo. Matrix Biol 29: 690-700.
Walton JR, Bowman NK, Khatib Y, Linklater J, Murrell GAC (2007) Restore orthobiologic implant: Not recommended for augmentation of rotator cuff repairs. J Bone Joint Surg-Am 89A: 786-791.

Wang X, Wu H, Zhang Z, Liu S, Yang J, Chen X, Fan M (2008) Effects of interleukin-6, leukemia inhibitory factor, and ciliary neurotrophic factor on the proliferation and differentiation of adult human myoblasts. Cell Mol Neurobiol 28: 113-124.

Warren GL, Hulderman T, Jensen N, McKinstry M, Mishra M, Luster MI, Simeonova PP (2002) Physiological role of tumor necrosis factor alpha in traumatic muscle injury. FASEB J 16: 1630-1632.

Wu X, Wang S, Chen B, An X (2010) Muscle-derived stem cells: isolation, characterization, differentiation, and application in cell and gene therapy. Cell Tissue Res 340: 549-567.

Yamanaka K, Matsumoto T (1994) The joint side tear of the rotator cuff. A followup study by arthrography. Clin Orthop Relat Res 304: 68-73.

Zalavras CG, Gardocki R, Huang E, Stevanovic M, Hedman T, Tibone J (2006) Reconstruction of large rotator cuff tendon defects with porcine small intestinal submucosa in an animal model. J Shoulder Elbow Surg 15: 224-231.

Zantop T, Gilbert TW, Yoder MC, Badylak SF (2006) Extracellular matrix scaffolds are repopulated by bone marrow-derived cells in a mouse model of achilles tendon reconstruction. J Orthop Res 24: 1299-1309.

Zheng MH, Chen J, Kirilak Y, Willers C, Xu J, Wood D (2005) Porcine small intestine submucosa (SIS) is not an acellular collagenous matrix and contains porcine DNA: possible implications in human implantation. J Biomed Mater Res B Appl Biomater 73: 61-67. 